Article

\title{
Determination of Macroelements, Transition Elements, and Anionic Contents of Commercial Roasted Ground Coffee Available in Jordanian Markets
}

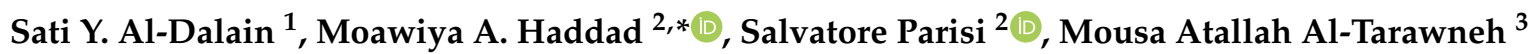 \\ and Haitham Qaralleh ${ }^{4}$ (D) \\ 1 Department of Medical Support, Al-Balqa Applied University, Al-Karak University College, \\ Al-Karak 61710, Jordan; Dr_sati2006@yahoo.com \\ 2 Department of Nutrition and Food Processing, Faculty of Agricultural Technology, Al-Balqa Applied \\ University, P.O.Box 206, Al-Salt 19117, Jordan; drparisi@inwind.it \\ 3 Medical Support Department, Faculty of Karak College, Al-Balqa Applied University, Al-Salt 19117, Jordan; \\ mousa19777@yahoo.com \\ 4 Department of Medical Laboratory Sciences, Mutah University, Mutah, Al-Karak 61710, Jordan; \\ haithym2006@yahoo.com \\ * Correspondence: haddad@bau.edu.jo
}

Received: 23 December 2019; Accepted: 2 March 2020; Published: 9 March 2020

\begin{abstract}
Coffee is one of the most common drinks worldwide. Due to the variability of elements composition, coffee is important for human health. The aim of this study is to assess the concentration of certain selected elements of commercial samples of roasted ground coffee available in Jordanian markets. The concentrations of macroelement components (sodium, potassium, and calcium), transition elements (lead, cadmium, iron, nickel, and copper), and anion contents (sulfate, nitrate, fluoride, chloride, and phosphate ions) have been determined in nine samples using atomic absorption spectroscopy. Obtained results showed that all tested samples contain macroelementscalcium, sodium, and potassium, in a concentration ranging from 6.18 to $162.6 \mu \mathrm{g} / \mathrm{gram}$ of dry weight (in detail: calcium, 6.96-9.81 $\mu \mathrm{g} / \mathrm{g}$; sodium, 121.54-162.60 $\mu \mathrm{g} / \mathrm{g}$; potassium, 6.18-10.23 $\mu \mathrm{g} / \mathrm{g})$. Regarding transition elements, all samples tested contained variable concentrations of iron and copper (1.26-2.07 and $0.24-0.66 \mu \mathrm{g} / \mathrm{g}$, respectively), while they lacked lead, cadmium, and nickel (only one sample contained $0.1 \mu \mathrm{g} / \mathrm{g}$ for nickel). In addition, all tested samples contained variable anionic concentrations. The lack of toxic selected elements (lead, cadmium, and nickel) in these samples appears to indicate the significance of these coffee samples as a source of useful selected elements for human health.
\end{abstract}

Keywords: anions; macroelements; Jordan; roasted coffee; transition elements

\section{Introduction}

Coffee is one of the most common drinks worldwide, with over 2.5 billion cups consumed daily. Globally, the coffee industry earns 60 billion dollars per year and is the most sought commodity after inedible crude oil. Consumption of coffee is variable among people based on their age, culture, and geographical distribution. Besides, coffee is consumed for its sensory characters. According to the International Coffee Organization, the highest consumption rate has been reported in Finland (12.0 kg per capita per year). In Jordan, the consumption rate of coffee is lower (about $3.3 \mathrm{~kg}$ per capita per year) [1]. Globally, 3 billion cups per day were consumed in 2019, according to the International Coffee Organization and International Coffee Day [2]. 
The effect of coffee consumption on human health has been previously studied. Reports showed that consumption of coffee is beneficial in several diseases such as Alzheimer's disease, Parkinson's disease, and diabetes mellitus type 2 [3,4]. In contrast, the consumption of coffee is considered a risk factor for the development of coronary heart disease and cancer [5-7].

Coffee beans contain a wide range of nutritional components, including proteins, carbohydrates, vitamins, and selected elements that appear to be the most significant components. At low concentrations, some of these elements are essential for living organisms, such as copper $(\mathrm{Cu})$, chromium (Cr), cobalt (Co), manganese (Mn), nickel (Ni), and zinc $(\mathrm{Zn})$. However, elements such as arsenic (As), cadmium (Cd), lead (Pb), mercury $(\mathrm{Hg})$, titanium (Ti), and uranium (U) are harmful to living organisms and should be avoided [8]. Reports showed that toxic selected elements induce oxidative damage, break down DNA, and induce cancer [9].

Due to the variability of selected elements, coffee is important for human health. Therefore, the aim of this study is to assess the concentration of certain selected elements in commercial samples of roasted ground coffee available in Jordanian markets. Concentrations of macroelements ( $\mathrm{Na}, \mathrm{K}$, and $\mathrm{Ca})$, transition elements $(\mathrm{Pb}, \mathrm{Cd}, \mathrm{Fe}, \mathrm{Ni}$, and $\mathrm{Cu})$, and anion contents-sulfate $\left(\mathrm{SO}_{4}{ }^{2-}\right)$, nitrate $\left(\mathrm{NO}_{3}{ }^{-}\right)$, fluoride $\left(\mathrm{F}^{-}\right)$, chloride $\left(\mathrm{Cl}^{-}\right)$, and phosphate $\left(\mathrm{PO}_{4}{ }^{3-}\right)$ - have been determined.

\section{Materials and Methods}

\subsection{Coffee Samples}

Coffee samples of different trade brands (named with codes from T1 to T9) were purchased from Jordanian markets. All samples were prepared in fine powder form, stored at room temperature not more than one day, and submitted to analyses immediately.

\subsection{Digestion Procedure}

A wet digestion method was used to extract heavy metals from coffee powder samples. For each sample, exactly $1.00 \mathrm{~g}$ was accurately measured using an OHAUS analytical balance with high accuracy $( \pm 0.0001 \mathrm{~g})$ and transferred to the pre-cleaned Teflon digestion vessels. Then, $10 \mathrm{~mL}$ of high-purity analytical reagent (AR) grade nitric acid $\left(\mathrm{HNO}_{3}, 65 \%\right)$ was added to each vessel, followed by an addition of 2 mLof high-purity AR grade perchloric acid or $\mathrm{HClO}_{4}$ (70\%). Subsequently, vessels were capped and transfer to the oven at $70{ }^{\circ} \mathrm{C}$ overnight. After the digestion, vessels were cooled, vent, and disassembled under fume hood. Then, samples extracted were quantitatively transferred to standard polyethylene volumetric flask and diluted to a final volume of $50 \mathrm{~mL}$ using deionized water. The diluted solution was filtrated using $0.7-\mu$ msyringe microfilters. Finally, the cleared solution after filtration was stored in a $50 \mathrm{~mL}$-polyethylene bottle and stored at $4{ }^{\circ} \mathrm{C}$ in the refrigerator until analysis time.

\subsection{Analytical Instrumentation and Calibration of Macroelements and Transition Elements}

$\mathrm{Ca}, \mathrm{Na}, \mathrm{K}, \mathrm{Ni}, \mathrm{Pb}, \mathrm{Cu}, \mathrm{Fe}$, and $\mathrm{Cd}$ were quantitatively analyzed based on internal calibration curves for series of standard solutions-from anhydrous calcium chloride, sodium chloride, potassium chloride, nickel (II) chloride, lead (II) chloride, copper (II) chloride, iron (III) chloride, and cadmium (II) chloride-using a double beam AA-6200 atomic absorption spectrophotometer (Thermo Jarrell Ash MODEL 757, Franklin, MA, USA). Working standards were prepared by means of a serial dilution of stock standard solutions $(1000 \mu \mathrm{g} / \mathrm{g}$ for each metal) purchased from Merck, Germany. Calibration curves for these elements were build-up by the instrument with best regression lines and related correlation coefficient $\left(\mathrm{r}^{2}>0.998\right.$; three measures into the AA-6200 instrument). The average value was used to build up the calibration curve $[10,11]$. 


\subsection{Analysis of Anions}

A water digestion was used to extract ions from coffee samples. For each sample, $1.00 \mathrm{~g}$ was accurately measured by analytical balance and transferred to a 200-mLflask, then boiled with $50 \mathrm{~mL}$ high-performance liquid chromatography (HPLC)-grade water for $15 \mathrm{~min}$. All flasks were cooled, then the samples extracts were filtrated using a $0.7-\mu \mathrm{m}$-microfilter, quantitatively transferred to a $100-\mathrm{mL}$ standard volumetric flask, and finally diluted to a final volume with HPLC-grade water. Five standard solutions for each ion were prepared; subsequently, samples and standard solutions were analyzed using a ion chromatography (Dionex model DX-I00, Sunnyvale, CA, USA) instrument. Calibration curves were plotted and ions concentrations were determined.

\subsection{Electric Conductivity and $p H$ of Coffee Solutions}

One gram of fine coffee powder for each sample was mixed with $50 \mathrm{~mL}$ HPLC-grade water. Samples were subsequently presented for $\mathrm{pH}$ and conductivity determination (directly related to ion concentration) using the electrode of an LF 537 conductivity meter (WTW, Weilheim, Germany). The conductivity is measured in millis/cm units.

\section{Results}

Concentrations of macroelements found in tested samples are displayed in Table 1. In general, all tested samples contain $\mathrm{Na}, \mathrm{K}$, and $\mathrm{Ca}$ as predominant elements.

Table 1. Amounts of macroelements ( $\mathrm{Na}, \mathrm{K}$, and $\mathrm{Ca}$ ) found in roasted ground coffee products available in Jordanian markets. Coffee samples are named with a dedicated acronym (from T1 to T9). Results (average values \pm standard deviation) are expressed as $\mu \mathrm{g} / \mathrm{gram}$ of dry weight of sampled coffee. The observed differencebetween observed $\mathrm{Ca}$ and $\mathrm{K}$ data series is not significant ( $t$-test, $p>0.05)$, while potassium is surely higher than calcium and sodium $(t$-test, $p<0.01)$.

\begin{tabular}{cccc}
\hline Roasted Ground Coffee Sample & Ca & K & Na \\
\hline T1 & $7.41 \pm 0.10$ & $145.81 \pm 0.32$ & $10.08 \pm 0.02$ \\
T2 & $7.97 \pm 0.06$ & $145.61 \pm 0.15$ & $7.80 \pm 0.02$ \\
T3 & $8.20 \pm 0.10$ & $146.72 \pm 0.15$ & $7.90 \pm 0.01$ \\
T4 & $8.76 \pm 0.06$ & $162.60 \pm 0.10$ & $10.23 \pm 0.01$ \\
T5 & $9.81 \pm 0.15$ & $121.54 \pm 0.26$ & $6.18 \pm 0.01$ \\
T6 & $8.33 \pm 0.15$ & $159.61 \pm 0.16$ & $6.52 \pm 0.02$ \\
T7 & $9.68 \pm 0.10$ & $139.95 \pm 0.21$ & $7.12 \pm 0.01$ \\
T8 & $8.89 \pm 0.01$ & $155.10 \pm 0.21$ & $8.49 \pm 0.01$ \\
T9 & $6.96 \pm 0.15$ & $134.23 \pm 0.276$ & $6.89 \pm 0.01$ \\
\hline
\end{tabular}

The concentrations of transition elements in all samples tested are summarized in Table 2.

Table 2. The concentrations of transition elements $(\mathrm{Pb}, \mathrm{Cd}, \mathrm{Fe}, \mathrm{Ni}$, and $\mathrm{Cu})$ found in roasted ground coffee products available in Jordanian markets. Coffee samples are named with a dedicated acronym (from T1 to T9). Results (average values \pm standard deviation, where possible) are expressed as $\mu \mathrm{g} / \mathrm{g}$ of dry weight of sampled coffee. The observed difference between observed Fe and $\mathrm{Cu}$ data series is significant $(t$-test, $p<0.01)$.

\begin{tabular}{cccccc}
\hline Roasted Ground Coffee Sample & $\mathbf{P b}$ & $\mathbf{C d}$ & $\mathbf{F e}$ & $\mathbf{N i}$ & $\mathbf{C u}$ \\
\hline T1 & Undetected & Undetected & $1.41 \pm 0.01$ & Undetected & $0.24 \pm 0.01$ \\
T2 & Undetected & Undetected & $1.26 \pm 0.01$ & Undetected & $0.61 \pm 0.03$ \\
T3 & Undetected & Undetected & $1.39 \pm 0.02$ & Undetected & $0.28 \pm 0.02$ \\
T4 & Undetected & Undetected & $1.51 \pm 0.02$ & Undetected & $0.29 \pm 0.01$ \\
T5 & Undetected & Undetected & $1.62 \pm 0.01$ & Undetected & $0.26 \pm 0.01$ \\
T6 & Undetected & Undetected & $1.75 \pm 0.01$ & Undetected & $0.26 \pm 0.02$ \\
T7 & Undetected & Undetected & $1.46 \pm 0.02$ & Undetected & $0.66 \pm 0.04$ \\
T8 & Undetected & Undetected & $1.78 \pm 0.02$ & Undetected & $0.26 \pm 0.01$ \\
T9 & Undetected & Undetected & $2.07 \pm 0.03$ & $0.10 \pm 0.03$ & $0.31 \pm 0.01$ \\
\hline
\end{tabular}


The concentrations of anions are summarized in Table 3. In general, all samples tested contain variable concentrations of $\mathrm{SO}_{4}{ }^{2-}, \mathrm{NO}_{3}{ }^{-}, \mathrm{F}^{-}, \mathrm{Cl}^{-}$, and $\mathrm{PO}_{4}{ }^{3-}$. The highest of these values was found with reference to ion $\mathrm{F}^{-}$with a maximum concentration of $16.3 \mu \mathrm{g} / \mathrm{g}$ of dry weight, while the lowest anion concentration was related to $\mathrm{NO}_{3}{ }^{-}$. Samples $\mathrm{T} 6$ and $\mathrm{T} 7$ were the richest samples with $\mathrm{SO}_{4}{ }^{2-}(12.1$ and $10.6 \mu \mathrm{g} / \mathrm{g}$, respectively). Sample T9 was the richest samples with $\mathrm{NO}_{3}{ }^{-}(2.24 \mu \mathrm{g} / \mathrm{g})$. In addition, samples T6, T7, T1, and T9 were the richest samples with $\mathrm{F}^{-}(16.2,15.1$, and $15.1 \mu \mathrm{g} / \mathrm{g}$, respectively). Moreover, samplesT2 and T6 were the richest samples with $\mathrm{Cl}^{-}$(3.32 and $3.31 \mu \mathrm{g} / \mathrm{g}$, respectively). Sample T5 was the richest samples with $\mathrm{PO}_{4}{ }^{3-}(3.5 \mu \mathrm{g} / \mathrm{g})$. It has to be considered that the difference between observed anions is significant ( $t$-test, $p<0.01)$ except for the comparison between $\mathrm{Cl}^{-}$and $\mathrm{PO}_{4}{ }^{3-}(t$-test, $p>0.05)$.

Table 3. The concentrations of anions $\left(\mathrm{SO}_{4}{ }^{2-}, \mathrm{NO}_{3}{ }^{-}, \mathrm{F}^{-}, \mathrm{Cl}^{-}\right.$, and $\left.\mathrm{PO}_{4}{ }^{3-}\right)$ found in roasted ground coffee products available in Jordanian markets. Coffee samples are named with a dedicated acronym (from T1 to T9). Results (average values \pm standard deviation) are expressed as $\mu \mathrm{g} / \mathrm{g}$ of dry weight of sampled coffee. The observed differencebetween observed anions is significant $(t$-test, $p<0.01)$ except for the comparison between $\mathrm{Cl}^{-}$and $\mathrm{PO}_{4}{ }^{3-}$ ( $t$-test, $p>0.05$ ).

\begin{tabular}{cccccc}
\hline Roasted Ground Coffee Sample & $\mathbf{S O}_{4}{ }^{2-}$ & $\mathbf{N O}_{3}{ }^{-}$ & $\mathbf{F}^{-}$ & $\mathbf{C l}^{-}$ & $\mathbf{P O}_{4}{ }^{\mathbf{3}^{-}}$ \\
\hline T1 & $7.63 \pm 0.21$ & $1.83 \pm 0.02$ & $15.19 \pm 0.41$ & $2.61 \pm 0.05$ & $2.56 \pm 0.03$ \\
T2 & $8.98 \pm 0.24$ & $1.74 \pm 0.01$ & $12.61 \pm 0.22$ & $3.32 \pm 0.07$ & $2.87 \pm 0.01$ \\
T3 & $7.48 \pm 0.18$ & $1.96 \pm 0.03$ & $13.97 \pm 0.28$ & $2.94 \pm 0.06$ & $2.88 \pm 0.06$ \\
T4 & $9.50 \pm 0.27$ & $1.95 \pm 0.02$ & $16.29 \pm 0.55$ & $2.84 \pm 0.03$ & $2.72 \pm 0.04$ \\
T5 & $1.73 \pm 0.17$ & $1.43 \pm 0.01$ & $3.48 \pm 0.24$ & $1.53 \pm 0.01$ & $3.46 \pm 0.08$ \\
T6 & $12.11 \pm 0.32$ & $1.96 \pm 0.01$ & $14.37 \pm 0.28$ & $3.31 \pm 0.01$ & $2.74 \pm 0.01$ \\
T7 & $10.60 \pm 0.25$ & $1.98 \pm 0.02$ & $16.20 \pm 0.51$ & $2.98 \pm 0.04$ & $2.70 \pm 0.01$ \\
T8 & $8.26 \pm 0.18$ & $1.83 \pm 0.04$ & $14.42 \pm 0.30$ & $2.64 \pm 0.07$ & $2.74 \pm 0.04$ \\
T9 & $5.51 \pm 0.12$ & $2.24 \pm 0.01$ & $15.07 \pm 0.17$ & $2.34 \pm 0.05$ & $2.72 \pm 0.04$ \\
\hline
\end{tabular}

The conductance and $\mathrm{pH}$ values for tested coffee solutions (coffee samples are named with a dedicated acronymfrom T1 to T9) are shown in Table 4. With reference to $\mathrm{pH}$ values for roasted coffees and related solutions, There are only a few data in the scientific literature. Some authors reported that the $\mathrm{pH}$ of brewed regular coffee may be from 4.95 to 5.45 , while decaffeinated coffee may give $\mathrm{pH}$ values in brewed coffee ranging from 5.16 to 5.80. Anyway, it has been reported that $\mathrm{pH}$ may be correlated with chlorogenic acids present in coffee [12].

Table 4. Conductance and $\mathrm{pH}$ values for tested coffee solutions (average values \pm standard deviation). Coffee samples are named with a dedicated acronym (from T1 to T9). Conductance is expressed as millis/cm, while $\mathrm{pH}$ values are expressed as $\log _{10}$ units.

\begin{tabular}{ccc}
\hline Sample No & $\mathbf{p H}\left(\mathbf{L o g}_{\mathbf{1 0}}\right.$ Units) & Conductance $(\mathbf{m i l l i S} / \mathbf{c m})$ \\
\hline T1 & $5.27 \pm 0.05$ & $530 \pm 15$ \\
T2 & $5.26 \pm 0.06$ & $517 \pm 11$ \\
T3 & $5.20 \pm 0.10$ & $561 \pm 12$ \\
T4 & $5.33 \pm 0.13$ & $597 \pm 22$ \\
T5 & $5.61 \pm 0.19$ & $403 \pm 11$ \\
T6 & $5.29 \pm 0.08$ & $582 \pm 22$ \\
T7 & $5.43 \pm 0.25$ & $554 \pm 13$ \\
T8 & $5.40 \pm 0.11$ & $576 \pm 20$ \\
T9 & $5.36 \pm 0.12$ & $536 \pm 25$ \\
\hline
\end{tabular}

\section{Discussion}

Roasted coffee samples have been previously analyzed. In general, roasted coffee contains selected elements in variable concentrations. Factors such as those able to influence the plantation and cultivation of coffee plants might conflict with the chemical composition of coffee beans. The types of soil and fertilizer used in coffee cultivation have been found to have some influence on their chemical 
composition [13]. Other factors potentially able to affect the concentration of selected elements include storage and transportation conditions and the procedure for roasted coffee preparation.

The concentration of $\mathrm{Na}$ is variable among samples tested. In general (Table 1), all tested samples contain $\mathrm{Na}, \mathrm{K}$, and $\mathrm{Ca}$ in a concentration ranging from 6.18 to $162.6 \mu \mathrm{g} / \mathrm{g}$ of dry weight. The macroelements content of coffee samples (T1 to T9) ranged from 121 to $162 \mu \mathrm{g} / \mathrm{g}$ (for K), 6.1 to $10.2 \mu \mathrm{g} / \mathrm{g}$ (for $\mathrm{Na}$ ), and 6.4 to $9.8 \mu \mathrm{g} / \mathrm{g}$ (for Ca). Potassium was the most dominant macroelement in all tested samples. Samples T4, T6, and T8 were the richest samples with K, whereas other tested samples contained lower K concentration (ranged from 146 to $121 \mu \mathrm{g} / \mathrm{g}$ ). The concentrations of Na are also variable among samples tested. Concentrations of $\mathrm{Na}$ in samples $\mathrm{T} 1$ and $\mathrm{T} 4$ were the highest while sodium was found in other analyzed samples with lower concentrations (the maximum amount did not exceed $8.4 \mu \mathrm{g} / \mathrm{g}$ of dry weight). Obtained results also showed that T5 and T7 were the richest samples with $\mathrm{Ca}(9.8$ and $9.6 \mu \mathrm{g} / \mathrm{g}$, respectively), whereas concentrations of $\mathrm{Ca}$ in other samples were in range from 8.8 to $7.4 \mu \mathrm{g} / \mathrm{g}$.

With reference to transition elements in tested samples (Table 2), these solutions contain variable concentrations of $\mathrm{Fe}$ and $\mathrm{Cu}$ while they lack $\mathrm{Pb}, \mathrm{Cd}$, and $\mathrm{Ni}$. The highest concentration of Fe was indicated in sample T9 $(2.07 \mu \mathrm{g} / \mathrm{g}$ of dry weight), while the highest concentration of $\mathrm{Cu}$ was indicated in sample T7 and T2 (0.66 and $0.61 \mu \mathrm{g} / \mathrm{g}$, respectively).

With relation to anions $-\mathrm{SO}_{4}{ }^{2-}, \mathrm{NO}_{3}{ }^{-}, \mathrm{F}^{-}, \mathrm{Cl}^{-}$, and $\mathrm{PO}_{4}{ }^{3-}-$ the highest value of reported data (Table 3) was found with reference to $\mathrm{F}^{-}$ion with a maximum concentration of $16.3 \mu \mathrm{g} / \mathrm{g}$ of dry weight, while the lowest anion concentration was related to $\mathrm{NO}_{3}{ }^{-}$. Samples $\mathrm{T} 6$ and $\mathrm{T} 7$ were the richest samples with $\mathrm{SO}_{4}{ }^{2-}\left(12.1\right.$ and $10.6 \mu \mathrm{g} / \mathrm{g}$, respectively). Sample T9 was the richest sample regarding $\mathrm{NO}_{3}{ }^{-}$ $(2.24 \mu \mathrm{g} / \mathrm{g})$. In addition, samples T6, T7, T1, and T9 were the richest samples with $\mathrm{F}^{-}(16.2,15.1$, and $15.1 \mu \mathrm{g} / \mathrm{g}$, respectively). Moreover, samples T2 and T6 were the richest samples with $\mathrm{Cl}^{-}$(3.32 and $3.31 \mu \mathrm{g} / \mathrm{g}$, respectively). Sample T5 was the richest sample regarding $\mathrm{PO}_{4}{ }^{3-}(3.5 \mu \mathrm{g} / \mathrm{g})$. It has to be considered that the differences between examined anions content are significant $(t$-test, $p<0.01)$ except for the comparison between $\mathrm{Cl}^{-}$and $\mathrm{PO}_{4}{ }^{3-}(t$-test, $p>0.05)$. To the best of our knowledge, this is the first report about the determination of these anions content in roasted coffee.

With reference to other results by different researchers, it was reported that coffee powder contains $\mathrm{K}$ in the concentration of $14,520 \mu \mathrm{g} / \mathrm{g}$ of dry weight followed by $\mathrm{Mg}(1968 \mu \mathrm{g} / \mathrm{g})$ and Ca $(946 \mu \mathrm{g} / \mathrm{g})$ [14]. However, the absence of $\mathrm{Pb}$ and $\mathrm{Cd}$ was observed; also, the roasted coffee beans contained the following elements and in this order: $\mathrm{K}>\mathrm{Mg}>\mathrm{Ca}>\mathrm{Na}>$ manganese $(\mathrm{Mn})>$ zinc $(\mathrm{Zn})>\mathrm{Cu}$ [15]. In the most part of available reports, the presence of microelements is in the following order: $\mathrm{Mn}>\mathrm{Zn}>\mathrm{Cu}>$ cobalt (Co), has been reported. Moreover, it has been reported that roasted coffee lacks toxic elements $\mathrm{Pb}$ and $\mathrm{Cd}$, which is in agreement with the present study [14-16]. Mn, $\mathrm{Cu}$, and $\mathrm{Zn}$ are reported in relatively high concentrations when speaking of roasted coffee [14-17]. Mn has been reported between 30.33 and $31.77 \mathrm{mg} / \mathrm{kg}$ in raw coffee samples [17]. Another study showed that Zn is presented in higher concentrations such as $19 \mathrm{mg} / \mathrm{kg}$ [14].

Generally, the $\mathrm{pH}$ of the coffee solution was in the range between 5.26 and 5.61, while the conductance was in the range between 403 to $597 \mathrm{milliS} / \mathrm{cm}$. As shown in Table 4 , as the $\mathrm{pH}$ of the coffee solutions increased, the conductance of the coffee solutions decreased. The highest $\mathrm{pH}$ observed value was for sample T5 (5.61), which also exhibitedthe lowest observed conductance (403 milliS $/ \mathrm{cm}$ ). These results are not in contrast with other reports concerning the relationship between chlorogenic acids and $\mathrm{pH}$; however, the influence of conductive ions dissolved in coffee solutions has to be considered when speaking of observed $\mathrm{pH}$ in this ambit.

From the nutritional viewpoint, many of detected elements should be considered for human health. As an example, the following dietary intakes are recommended for women and men when speaking of copper: 1.0-1.1 and 1.2-1.6 mg/day, respectively [18]. These data may be important when speaking of observed intakes from supplements in well-determined geographical areas or countries such as the United States of America, showing a substantial similarity between recommended intakes and real supplemental copper intakes [19]. A few data are available in this ambit: some importantdetail 
might be reported for nickel, correlated with the consumption of several foods including coffee [18]. However, it is difficult to obtain reliable assumptions and theoretical data in this context because of two factors: (1) the bioavailability of selected elements depends on coffee varieties with notable differences [13-17,19-21], and (2) there are different procedures for aqueous extraction of elements with the consequent and remarkable variability of results concerning elements (while theoretical values should be assumed as a general reference).

It has been reported that espresso coffee may contain the following elements: $\mathrm{Ca}, 20 \mu \mathrm{g} / \mathrm{g}$ of coffee solution; Na, $20 \mu \mathrm{g} / \mathrm{g} ; \mathrm{Fe}, 1 \mu \mathrm{g} / \mathrm{g} ; \mathrm{K}, 540 \mu \mathrm{g} / \mathrm{g} ; \mathrm{Cu}, 0.07 \mu \mathrm{g} / \mathrm{g}$ [20]. On these bases, and considering dietary intakes of selected minerals in the United States (1999-2000, males, age: 40-59), it could be calculated that one gram of espresso coffee may give $0.02 \%$ per day with relation to calcium; $4.7 \times 10^{-3} \%$ per day (copper); $5.7 \times 10^{-3 \%}$ per day (iron); $0.8 \%$ per day (potassium); $4.8 \times 10^{-4 \%}$ per day (sodium). In other words, similar beverages can be a good source when speaking of $\mathrm{K}$ and $\mathrm{Ca}$, while $\mathrm{Cu}, \mathrm{Fe}$, and $\mathrm{Na}$ intakes would be low. On the other hand, our data might be used to calculate analogous intakes per gram of roasted coffee: as a simple example, one gram of roasted coffee (dry weight) would give $3.8 \times 10^{-5} \%$ per day of calcium. The difference between reported results (20 against $8.45 \mu \mathrm{g} / \mathrm{g}$ ) for calcium depends on the source (espressocoffee vs. roasted coffee) and also on the original water content (of calcium).

Among the tested macroelements, $\mathrm{K}$ was the most dominant element with a maximum concentration equal to $162 \mu \mathrm{g} / \mathrm{g}$ of dry weight. It is known as an intracellular cation that possesses a significant role in water balance. Also, potassium has a vital role in nervous system regulation [22]. However, concentrations of $\mathrm{Na}$ and $\mathrm{Ca}$ were fourteen to twenty times less than $\mathrm{K}$ concentration in all tested coffee samples. In addition (Table 1), Na was the second major component in coffee samples. In addition to its vital role in the formation of action potential, Na contributes to water balance outside the cell and in acid-base balance. Calcium is one of the most significant macroelements for creating and maintaining the structure of teeth and bones and muscle performances, with other important effects concerning nervous and cardiovascular systems [23].

Among transition elements evaluated in coffee samples, only Fe and $\mathrm{Cu}$ were reported. The presence of $\mathrm{Fe}$ and $\mathrm{Cu}$ at low concentrations does not minimize their biological roles. Copper is essential for the production of melanin, while iron is the most essential element for the production and functioning of red blood cells.

\section{Conclusions}

The result of this study show that the coffee samples available in Jordanian markets are a good source of essential elements. Additionally, they lack toxic elements (lead, cadmium, and nickel). For this and other reasons concerning public health and food safety, the significance of these coffee samples as a source of useful selected elements for human health should be reassessed. More research is needed in this ambit, also considering the low number of scientific literature available when speaking of the abundance of selected anions in roasted coffee.

Author Contributions: Conceptualization, S.Y.A.-D. and M.A.H.; Data curation, M.A.H. and H.Q.; Formal analysis, S.Y.A.-D.; Investigation, S.Y.A.-D.; Methodology, S.Y.A.-D.; Project administration, H.Q.; Resources, S.Y.A.-D.; Supervision, H.Q.; Validation, S.Y.A.-D.; Visualization, S.Y.A.-D.; Writing—original draft, S.Y.A.-D.; Writing-review \& editing, M.A.H., S.P. and M.A.A.-T. All authors have read and agreed to the published version of the manuscript.

Funding: This research received no external funding.

Conflicts of Interest: The authors declare no conflict of interest.

\section{References}

1. Food Balance Sheet. Jordan. Available online: http://www.dos.gov.jo/dos_home_e/main/agriculture/food_ budget/index.htm (accessed on 9 December 2019). 
2. International Coffee Day. Available online: http://www.ico.org/annual_review.asp?section=About_Us (accessed on 9 December 2019).

3. Gongora-Alfaro, J.L. Caffeine as a preventive drug for Parkinson's disease: Epidemiologic evidence and experimental support. Rev. Neurol. 2010, 50, 221-229. (In Spanish) [PubMed]

4. Hjellvik, V.; Tverdal, A.; Strøm, H. Boiled coffee intake and subsequent risk for type 2 diabetes. Epidemiology 2011, 22, 418-421. [CrossRef] [PubMed]

5. Montagnana, M.; Favaloro, E.J.; Lippi, G. Coffee intake and cardiovascular disease: Virtue does not take center stage. Semin. Thromb. Hemost. 2012, 38, 164-177. [CrossRef] [PubMed]

6. Silvera, S.A.; Jain, M.; Howe, G.R.; Miller, A.B.; Rohan, T.E. Intake of coffee and tea and risk of ovarian cancer: A prospective cohort study. Nutr. Cancer 2007, 58, 22-27. [CrossRef] [PubMed]

7. Sugiyama, K.; Kuriyama, S.; Akhter, M.; Kakizaki, M.; Nakaya, N.; Ohmori-Matsuda, K.; Shimazu, T.; Nagai, M.; Sugawara, Y.; Hozawa, A.; et al. Coffee consumption and mortality due to all causes, cardiovascular disease, and cancer in Japanese women. J. Nutr. 2010, 140, 1007-1013. [CrossRef] [PubMed]

8. Schmidt, C.A.P.; Miglioranza, E.; Nagashima, G. Heavy metals concentration in coffee grains produced in farming under basalt soil and Caiuá sandstone. Cienc. Rural 2009, 39, 1590-1593.

9. Wallkers, M.P. Cadmium carcinogenesis. Mutat. Res. 2003, 533, 107-120. [CrossRef] [PubMed]

10. Al-Dalain, S.Y.; Abu-Darwish, M.S.; Al-Fraihat, A.H.; Al-Dabbas, F.M.; Al-Dalin, H.K.; Al-Hamaidah, K.D. Comparative studies of the trace elements content of some herbal tea consumed in Jordan. Pak. J. Nutr. 2012, 11, 818-820. [CrossRef]

11. Abu-Darwish, M.S.; Al-Fraihat, A.H.; Al-Dalain, S.Y.; Afifi, F.M.U.; Al-Tabbal, J.A. Determination of Essential Oils and Heavy Metals Accumulation in Salvia officinalis Cultivated in three Intra-raw Spacing in Ash-Shoubak, Jordan. Int. J. Agric. Biol. 2011, 13, 981-985.

12. Fujioka, K.; Shibamoto, T. Chlorogenic acid and caffeine contents in various commercial brewed coffees. Food Chem. 2008, 106, 217-221. [CrossRef]

13. Martin, M.J.; Pablos, F.; Gonzalez, A.G. Characterization of Green Coffee Varieties According to Their Metal Content. Anal. Chim. Acta 1998, 358, 177-183. [CrossRef]

14. Ashu, R.; Chandravanshi, B.S. Concentration levels of metals in commercially available Ethiopian roasted coffee powders and their infusions. Bull. Chem. Soc. Ethiop. 2011, 25, 11-24. [CrossRef]

15. Gebretsadik, A.T.; Berhanu, T.; Kefarge, B. Levels of selected essential and nonessential metals in roasted coffee beans of Yirgacheffe and Sidama, Ethiopia. Am. J. Environ. Protect. 2015, 4, 188-192. [CrossRef]

16. Grembecka, M.; Malinowska, E.; Szefer, P. Differentiation of market coffee and its infusions in view of their mineral composition. Sci. Total Environ. 2007, 383, 59-69. [CrossRef] [PubMed]

17. Dos Santos, E.J.; deOliveira, E.J. Determination of Mineral Nutrients and Toxic Elements in Brazilian Soluble Coffee by ICP-AES. Food Comp. Anal. 2001, 14, 523-531. [CrossRef]

18. Trumbo, P.; Yates, A.A.; Schlicker, S.; Poos, M. Dietary reference intakes: Vitamin A, vitamin K, arsenic, boron, chromium, copper, iodine, iron, manganese, molybdenum, nickel, silicon, vanadium, and zinc. J. Acad. Nutr. Diet. 2001, 101, 294-301.

19. Moss, A.J.; Levy, A.S.; Kim, I.; Park, Y.K. Use of Vitamin and Mineral Supplements in the United States: Current Users, Types of Products, and Nutrients. Adv. Data Vital Health Stat. 1989, 174, 1-20.

20. Magnati, G.; Russo, C.; Dazzi, D. NutrizioneClinica; EdiSES s.r.l.: Napoli, Italy, 1997; ISSN 8879591339.

21. Morgano, M.A.; Pauluci, L.F.; Mantovani, D.M.B.; Mory, E.E.M. Determinação de mineraisem café cru. Rev. Cienc. Agrotecnol. 2002, 22, 19-23.

22. Powell, J.J.; Burden, T.J.; Thompson, R.P.H. In vitro mineral availability from digested tea: A rich dietary source of manganese. Analyst 1998, 123, 1721-1724. [CrossRef] [PubMed]

23. Ahmed, I.; Zaidi, S.S.H.; Khan, Z.A. The determination of major, minor and trace elements in tea, tea liquor, instant coffee and cocoa samples. Pak. J. Sci. Ind. Res. 1989, 32, 513-515.

(C) 2020 by the authors. Licensee MDPI, Basel, Switzerland. This article is an open access article distributed under the terms and conditions of the Creative Commons Attribution (CC BY) license (http://creativecommons.org/licenses/by/4.0/). 